\title{
Human population, economic activities, and wild bird conservation in Mexico: factors influencing their relationships at two different geopolitical scales
}

\section{Población humana, actividades económicas y conservación de aves silvestres en México: factores que influencian sus relaciones en dos escalas geopolíticas diferentes}

\author{
Xavier López-Medellín ${ }^{1 凶}$, Adolfo G. Navarro-Sigüenza² and Gerardo Bocco ${ }^{3}$ \\ ${ }^{1}$ Centro de Investigaciones en Ecosistemas, Universidad Nacional Autónoma de México . Antigua Carretera a Pátzcuaro No. 8701. Col. Ex-Hacienda \\ de San José de La Huerta, 58190 Morelia, Michoacán, México. \\ ${ }^{2}$ Museo de Zoología, Facultad de Ciencias, Universidad Nacional Autónoma de México. Apartado postal 70-399, Coyoacán 04510 México, D.F., \\ México. \\ ${ }^{3}$ Centro de Investigaciones en Ecosistemas, Universidad Nacional Autónoma de México, Antigua Carretera a Pátzcuaro No. 8701,58190 Morelia, \\ Michoacán, México. \\ \xlmedellin@oikos.unam.mx
}

\begin{abstract}
Population growth poses threats to biodiversity, specifically to sensitive species. Therefore, an understanding of the conflict between biodiversity and human population is needed to enable long-term planning of development and conservation policies by state and federal governments and society based on limitations and potentials of environments. We used a geopolitical approach to analyze data on human demography, economic activities, natural vegetation, avian diversity, and protected areas of the 32 states of Mexico and the 30 districts of the state of Oaxaca. Using factor analysis, we identified the biodiversity-rich geopolitical units that have a large human population and are developing intense economic activities. We then carried out a series of linear regressions between the resulting factors to test whether they were related, suggesting areas where conservation conflicts may exist, and found that relations between human activities and natural resources vary from region to region. These results help us identify geopolitical units that require detailed studies of the interactions between population and natural resources, and also highlight the importance of using geopolitical scales as study units, where most conservation and development policies are determined, to inform local stakeholders and decision makers.
\end{abstract}

Key words: biodiversity, sustainability, Oaxaca, poverty.

Resumen. El crecimiento humano representa amenazas para la biodiversidad, especialmente para especies sensibles. Se necesita conocer a fondo el conflicto que representa el crecimiento de la población para la biodiversidad y llevar a cabo políticas y acciones a largo plazo de actividades de desarrollo y conservación evaluadas por gobiernos federales y estatales, basándose en las limitaciones y potenciales de los ecosistemas. Utilizamos una aproximación geopolítica para analizar variables de demografía humana, actividades económicas, superficie de vegetación, diversidad de aves y áreas protegidas de los 32 estados de México y los 30 distritos de Oaxaca. Mediante un análisis de factores, identificamos las entidades geopolíticas con más biodiversidad con alta población humana y que desarrollan intensamente actividades económicas. Posteriormente realizamos regresiones lineales entre los factores para analizar su interrelación, lo que sugiere áreas en las que la conservación está amenazada, encontrando que estas relaciones varían en cada región. Estos resultados identifican las unidades geopolíticas que requieren un estudio detallado de la interacción entre población y recursos naturales y resaltan la importancia de utilizar una escala geopolítica, que es el nivel donde se determinan la mayor parte de las políticas de conservación y desarrollo, para proveer información detallada a usuarios y tomadores de decisiones.

Palabras clave: biodiversidad, sustentabilidad, Oaxaca, pobreza.

\section{Introduction}

Human activities have interfered with natural ecosystems in several ways throughout history and are one of the main causes of flora and fauna extinctions (Ehrlich,

Recibido: 16 abril 2010; aceptado: 30 mayo 2011
1995; Soulé and Sanjayan, 1998; Thompson and Jones, 1999; Waide et al., 1999; Seabloom et al., 2002). Climate change, pollution, and resource over-exploitation are involved in the decline of natural populations worldwide (Iñigo-Elías and Ramos, 1991; Ehrlich, 1995; Maurer, 1996; Ehrlich and Ceballos, 1997; Ceballos and Márquez, 2000). It is estimated that the number of threatened bird species per country has increased by $30 \%$ due to human 
population growth (Kerr and Currie, 1995; McKinney, 2002) and recent estimates suggest that human population will reach 9 billion people within the next fifty years (Lutz et al., 2001). To satisfy the demands of this increasing population, economic activities are growing at accelerated rates with serious environmental consequences (Kerr and Currie, 1995; Tilman et al., 2001; Seabloom et al., 2002; Luck et al., 2004; Vázquez and Gaston, 2006). Furthermore, the resources needed by about half of the human population are mainly obtained from inter-tropical developing countries, which experience the most drastic negative land use conversions (Velázquez et al., 2003).

Among such economic activities, cattle grazing and agriculture in particular remove millions of hectares of natural vegetation, and where practiced without appropriate methods, they cause severe pollution of soil, air, and water (Soulé, 1991; Ehrlich, 1995; Tilman et al., 2001). Human activities are more intensely practiced on soils that harbor a myriad of ecosystems due to their high productivity (Cincotta et al., 2000; Araújo, 2003; Burguess et al., 2007). Such activities reach the highest conversion rates in the tropics, where growing deforestation fragments habitats and limits the distribution of species at alarming rates (Brooks et al., 1999; Waide et al., 1999; Balmford et al., 2001; Seabloom et al., 2002; Velázquez et al., 2003; Ricketts et al., 2005). Since human activities normally implicate vegetation removal, a serious balance between development and conservation must be evaluated to reduce natural risks while sustaining healthy economic activities (Tilman et al., 2001; Vázquez and Gaston, 2006).

Agriculture and cattle grazing are the most important causes of natural habitat transformation and soil degradation in Mexico (Ceballos, 1993; Ehrlich and Ceballos, 1997). Between 1976 and 2000, 90000 ha of temperate forests, 265000 ha of tropical forests and 195000 ha of scrublands were transformed to human use areas, representing a deforestation rate of $0.25 \%, 0.76 \%$ and $0.33 \%$ per ecosystem respectively (Maas et al., 2004). Since population increase demands higher production from these activities, a full understanding of the relationships between natural resources and human activities is needed. This will help to identify areas where conservation conflicts are likely to be severe and thus, plan the development and activities in a sustainable fashion (Waide et al., 1999; Seabloom et al., 2002; Velázquez et al., 2003; Luck et al., 2004; Vázquez and Gaston, 2006).

Several studies have explored human activities and their impacts on the environment (e.g. Bawa and Dayanandan, 1997; Peterson et al., 2000; Balmford et al., 2001; Chown et al., 2003; Burguess et al., 2007). These studies focus on very large (e.g. nationwide) areas, using coarse geographic scales for their analyses. In such cases, grids are displayed over the study region and values for biodiversity and human activities are given per cell. All these analyses conclude that the interactions among environmental and socioeconomic variables vary depending on the studied region and the geographical scale of the analysis, and recommend examining such interactions at finer geographic scales to allow a more detailed identification of the resulting effects of the interaction between human population and natural resources at local levels (Peterson et al., 2000; Balmford et al., 2001; Chown et al., 2003). Since such studies based their analyses on grids, they do not consider geopolitical limits; therefore they do not account for administrative and economic boundaries. This is important because geopolitical and geoeconomic entities (e.g. country, states, or municipalities: areas defined by political boundaries) are administered by different levels of government, each with its own environmental and economic attributions, priorities, policy formulations, and monitoring and conservation activities. Sometimes economic development and natural resource conservation policies are difficult to apply, because different governmental levels and institutions follow their own objectives and/or agendas. The development of a common vision among such levels is fundamental for the successful protection of the environment and the sustainable development of the country. This endeavor can be fostered by scientific studies that integrate both geopolitical perspectives in their analysis to strengthen policy and decision making.

In this study we explore the relationships between geographic, socio-economic, and environmental variables at 2 geopolitical levels in Mexico. The results allowed us to categorize the states of Mexico and the districts of the state of Oaxaca according to their biodiversity features and the dimension of economic activities practiced in each one. This study aims to identify areas of conservation conflicts in the light of development and human population. By applying the same methodology to different geopolitical scales we intend to evaluate the effectiveness of this methodology to strengthen the general knowledge of the states considered a priority for conservation in Mexico, as well as particular regions within the state of Oaxaca.

We selected the state of Oaxaca because it was the only one that had information on avian species geospatially located, as a result of an extensive research and data collection made by Navarro and collaborators. This allowed us to identify the number of bird species per each district. We decided to use the districts of Oaxaca, rather than municipalities, because there are a total of 570 municipalities in the state (almost $25 \%$ of all municipalities in the country), so it represented a very large number for the analysis, therefore since the state is also divided into 30 districts we used these units for our state level analysis. 


\section{Materials and methods}

Variables related to land surface, human demography, primary economic activities, natural vegetation, avian richness, and protected areas were incorporated into a data matrix. We selected a total of 16 variables for the national level that includes the 32 states of Mexico (Fig. 1) and 13 variables for the state level that includes the 30 districts of the state of Oaxaca (Fig. 2) (Table 1).

We performed Factor Analysis based on a correlation matrix using Statistica software v. 5.5 to reduce the number of variables and to generate a new set of non-correlated ones. National data were analyzed independently from the state of Oaxaca data. According to the Kaiser criterion (Johnson, 1998), the factors with eigenvalues higher than 1 were selected. To maximize the loadings in each factor, we used a Varimax rotation that distributes the variance in data across the selected factors. Factors were labeled according to the variables with highest loadings on each. Variables with low loading values were included in the analyses as independent variables. We then performed a series of linear regressions using the factor scores to explore relations between factors and independent variables. Finally, with these results we compared each experimental unit (states in the national analysis and districts in the state analysis) according to the factors that represent opportunities and threats for the conservation of natural resources.

Total and natural vegetation surface variables at the state and district levels are expressed in square kilometers. These were obtained from the official government information source, the National Institute of Statistics, Geography and Informatics (INEGI) (http://www.inegi. gob.mx).

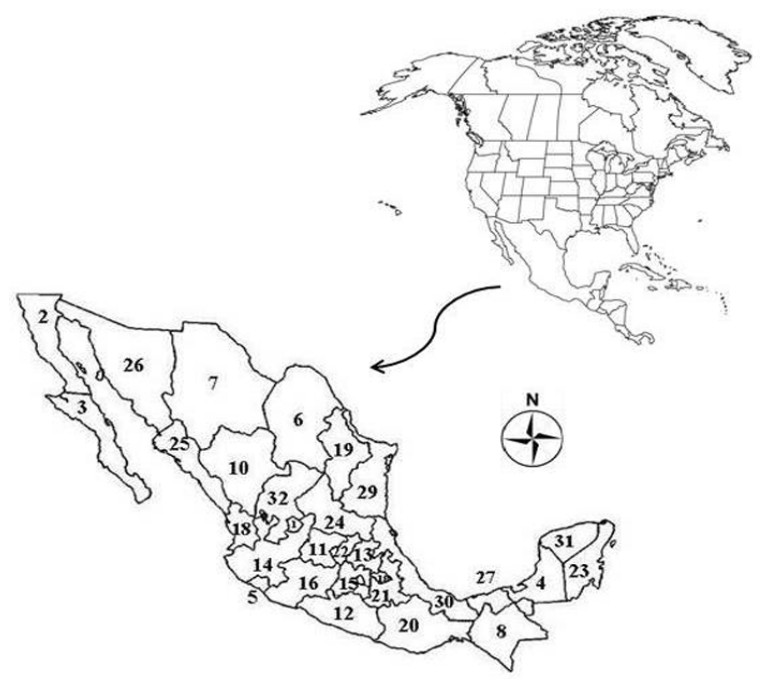

Figure 1. States of Mexico.

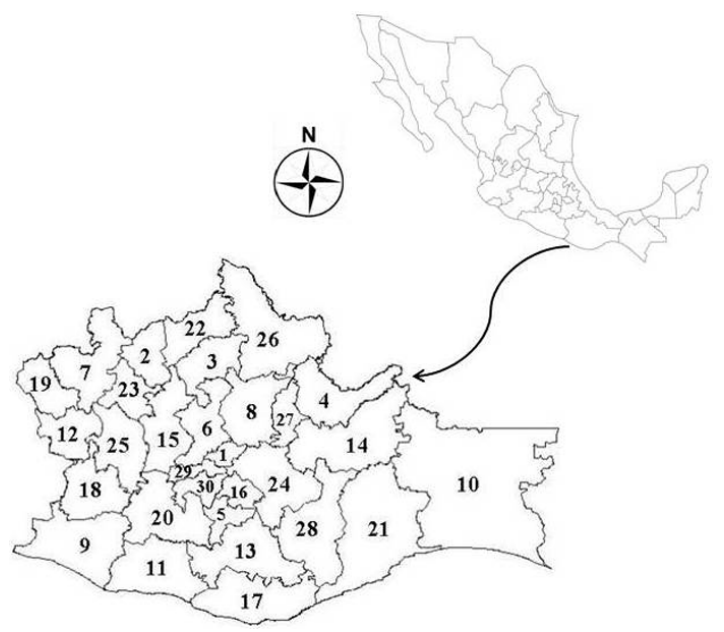

Figure 2. Districts of the state of Oaxaca.

Table 1. Variables included in the analyses at both, the national and state level

\begin{tabular}{ll}
\hline National level & State level \\
\hline State surface & Total surface \\
$\%$ of national territory & $\%$ of district surface in the total state surface \\
Cropland surface & Cropland surface \\
$\%$ of the state used for cropland & $\%$ of the district surface used for cropland \\
Cattle production & Cattle production \\
Total population & Total population \\
Rural population & Population density \\
Rural population density & Total bird species \\
Poverty index & Endemic to Mexico bird species \\
Natural vegetation surface & Endangered bird species by Mexican laws \\
$\%$ of state territory covered by natural vegetation & Natural vegetation surface \\
Protected area surface & $\%$ of the district surface with natural vegetation \\
$\%$ of state territory protected & Poverty index \\
Total bird species & Public investment for agriculture and cattle grazing activities \\
Endemic to Mexico bird species & \\
Endangered bird species to Mexican laws & \\
\hline
\end{tabular}


The human population data included in the analyses corresponds to the 2003 census (INEGI). For the national analysis we used total population, rural population, and population density. For the state analysis, we included total population and population density; rural population data were not available. In both analyses we included a poverty index developed in 2000 by the National Council of Population (CONAPO, 2001), which involves different variables that measure human livelihood such as the availability of water, electricity and sanitation, education, housing materials, number of rooms and inhabitants, income, etc.

The cropland surface in square kilometers and cattle production in tons were incorporated in both geopolitical analyses using data from censuses by INEGI (INEGI, 2003).

Besides the natural vegetation surface, we considered avian population information as a means to measure biodiversity in each unit for both geopolitical analyses. This information represents the total number of birds species recorded and was obtained from an unpublished database compiled by Adolfo Navarro and collaborators of the georeferenced bird records of Mexico based on scientific collections, recent literature, and intensive field work. The information on the number of endemic species was obtained from González-García and Gómez de Silva (2002), and the number of endangered bird species was obtained from the 2001 national list of endangered species (DOF, 2002).

The amount of land area in hectares of each state that was declared as natural protected area by the federal government until 2006 (regardless of their category) was obtained from the National Commission of Natural Protected Areas (CONANP http://www.conanp.gob.mx). We also included a variable representing the percentage of each state's surface that was protected. The information on protected areas in Oaxaca was not available at the district level; therefore it was not included in the state analysis.

Information on avian species richness at the state level included in this analysis is based on more than 20000 bird records from 736 species ( $67 \%$ of the avifauna of Mexico). Of this total, 61 species are endemic to Mexico and 195 species are included on the national endangered list, which makes Oaxaca the state with more endangered bird species in the country (Navarro et al., 2004).

\section{Results}

National analysis. We selected 4 factors that explained $72.3 \%$ of the variance in the data (Table 2). Factor 1 was labeled "Natural vegetation factor", since variables of state land area (ST_AREA), the percentage of the surface of the state in relation to the national surface (NAT\%ST_A), natural vegetation surface (NAT_VEG), and the percentage of natural vegetation surface in relation to the surface of the state (\%NATVEG) were highly correlated between them, showing higher loading values. Factor 2 was labeled "Cattle and human factor" because the high loading variables were cattle and meat production (CATTLE and MEAT) and human population (TOT_POP). The third factor was influenced by the poverty index (POV_IND), rural population (RUR_POP), and endangered species (ENDANGRD), so we labeled it "Poverty and endangered species factor". Finally the fourth factor, labeled "Protected areas factor" was represented by the surface of protected areas (PA) and the percentage of protected area of each state $(\% \mathrm{PA})$. Four of the original variables (cropland surface (CROPLND), total species (TOTAL_SP), and endemic species (ENDEMIC) presented low values of loadings in all factors and therefore were analyzed as independent variables of the FA (Table 3).

The factors and independent variables considered as opportunities for conservation were natural vegetation, total species, and endemic species. Those considered as threats to conservation were the cattle and human factor, poverty and endangered species factor, and cropland surface. The protected areas factor was analyzed independently to determine if the protection scheme is suitable to cope with the state's present environmental situation.

Five linear regressions between factors and independent variables were found to be significant (Table 4). Among these, poverty and endangered factor vs. Endemic species correlated marginally, where states with many endemic species like Oaxaca, Guerrero, Puebla, and Michoacán also have high levels of poverty and endangered species (Fig. 3A). The protected areas factor was negatively related to endemic species, indicating that some states with high avian endemism like Oaxaca, Guerrero, Michoacán, and Sinaloa have less protected surface (Fig. 3B). Total bird species and endemic species were also correlated, indicating that some states with many wild bird species, like Oaxaca, Puebla, Michoacán, Sinaloa, Jalisco, Nayarit, and Veracruz also have many endemic species. Other states like Guerrero, Colima, or Estado de México have fewer

Table 2. Eigenvalues and percentage of the variance explained by the first 4 factors resulting from FA in the national analysis

\begin{tabular}{|c|c|c|c|c|}
\hline Factor & Eigenval & $\begin{array}{l}\% \text { total } \\
\text { Variance }\end{array}$ & $\begin{array}{c}\text { Cumul. } \\
\text { Eigenval }\end{array}$ & $\begin{array}{c}\text { Cumul. } \\
\%\end{array}$ \\
\hline 1 & 5.834533 & 29.17266 & 5.83453 & 29.17266 \\
\hline 2 & 4.722973 & 23.61486 & 10.55751 & 52.78753 \\
\hline 3 & 2.266249 & 11.33125 & 12.82375 & 64.11877 \\
\hline 4 & 1.638992 & 8.19496 & 14.46275 & 72.31374 \\
\hline
\end{tabular}


Table 3. Loadings and communalities for each variable in the FA for the national analysis

\begin{tabular}{|c|c|c|c|c|c|c|c|c|c|c|}
\hline Loadings & $\begin{array}{c}\text { Factor } \\
1 \\
\end{array}$ & $\begin{array}{c}\text { Factor } \\
2 \\
\end{array}$ & $\begin{array}{c}\text { Factor } \\
3 \\
\end{array}$ & $\begin{array}{c}\text { Factor } \\
4 \\
\end{array}$ & Communalities & $\begin{array}{l}\text { From } 1 \\
\text { Factor }\end{array}$ & $\begin{array}{l}\text { From } 2 \\
\text { Factors }\end{array}$ & $\begin{array}{l}\text { From } 3 \\
\text { Factors }\end{array}$ & $\begin{array}{l}\text { From } 4 \\
\text { Factors }\end{array}$ & $\begin{array}{l}\text { Multiple } \\
\text { R-Square }\end{array}$ \\
\hline ST_AREA & 0.961281 & 0.017394 & 0.119602 & 0.074443 & & 0.238781 & 0.872569 & 0.921812 & 0.942557 & 0.999246 \\
\hline NAT $\%$ ST_A & 0.959457 & 0.014527 & 0.111579 & 0.066903 & & 0.245463 & 0.866950 & 0.917231 & 0.936687 & 0.999032 \\
\hline ENDANGRD & 0.144257 & 0.011768 & 0.886036 & -0.085378 & & 0.053655 & 0.452303 & 0.889272 & 0.907226 & 0.948403 \\
\hline HARVEST & 0.010324 & 0.685583 & 0.042038 & -0.048274 & & 0.153670 & 0.209196 & 0.329907 & 0.472748 & 0.729103 \\
\hline ENDEMIC & 0.037233 & 0.281957 & 0.360074 & 0.411524 & & 0.194112 & 0.320086 & 0.320214 & 0.356909 & 0.596084 \\
\hline TOTAL_SP & 0.42066 & 0.247975 & 0.562637 & 0.216018 & & 0.122132 & 0.601716 & 0.758443 & 0.761770 & 0.930265 \\
\hline NAT_VEG & 0.957026 & -0.05852 & -0.063215 & 0.026412 & & 0.381650 & 0.821739 & 0.907662 & 0.929705 & 0.996205 \\
\hline$\%$ NATVEG & 0.766086 & -0.16883 & -0.15953 & -0.346534 & & 0.564450 & 0.724133 & 0.742673 & 0.762853 & 0.923029 \\
\hline PA & 0.258048 & -0.143722 & -0.156915 & -0.722509 & & 0.346699 & 0.347735 & 0.354735 & 0.643846 & 0.928036 \\
\hline$\%$ PA & -0.130806 & -0.173358 & -0.20978 & -0.762324 & & 0.169885 & 0.308691 & 0.340994 & 0.692557 & 0.920541 \\
\hline CROPLND & 0.20111 & 0.399453 & 0.560649 & 0.342194 & & 0.253932 & 0.741701 & 0.753097 & 0.760900 & 0.939163 \\
\hline TOT_POP & -0.119895 & 0.749521 & 0.18472 & 0.096546 & & 0.378020 & 0.442960 & 0.534697 & 0.619029 & 0.855710 \\
\hline RUR_POP & -0.114223 & 0.406514 & 0.800741 & 0.157587 & & 0.449480 & 0.713551 & 0.820052 & 0.832217 & 0.971917 \\
\hline POV_IND & -0.193032 & -0.16502 & 0.847707 & 0.025656 & & 0.120214 & 0.204776 & 0.749380 & 0.751285 & 0.933486 \\
\hline MEAT & -0.059091 & 0.958054 & 0.084393 & 0.13159 & & 0.458764 & 0.556759 & 0.824691 & 0.947362 & 0.993260 \\
\hline CATTLE & -0.117619 & 0.95341 & 0.037746 & 0.124047 & & 0.474371 & 0.531976 & 0.812245 & 0.940592 & 0.993465 \\
\hline EXP..VAR & 5.028476 & 3.65276 & 3.301703 & 2.479809 & & & & & & \\
\hline PRP.TOTL & 0.251424 & 0.182638 & 0.165085 & 0.12399 & & & & & & \\
\hline
\end{tabular}

Table 4. Results from regressions at the national and state levels

\begin{tabular}{lccc}
\hline Regressions at the national level & $R^{2}$ & $p$ & $G L$ \\
\hline $\begin{array}{l}\text { Poverty and endangered factor vs. } \\
\text { Endemic species }\end{array}$ & 0.13 & 0.05 & 31 \\
$\begin{array}{l}\text { Protected areas factor vs. Endemic } \\
\text { species }\end{array}$ & 0.15 & 0.03 & 31 \\
$\begin{array}{l}\text { Total bird species vs. Endemic } \\
\text { species }\end{array}$ & 0.2 & 0.01 & 31 \\
$\begin{array}{l}\text { Cropland surface vs. Total species } \\
\text { Cropland surface vs. Endemic }\end{array}$ & 0.05 & $<0.0001$ & 31 \\
species & 0.19 & 0.01 & 31 \\
$\begin{array}{l}\text { Regressions at the state level } \\
\text { Factor 1 vs. Cattle production }\end{array}$ & 0.27 & 0.003 & 29 \\
$\begin{array}{l}\text { Natural vegetation factor vs. } \\
\text { Endemic species }\end{array}$ & 0.18 & 0.02 & 29 \\
\hline
\end{tabular}

total species but a high number of endemics (Fig. 3C). Finally, there is a relationship between cropland surface vs. total species, where states such as Oaxaca, Veracruz, and Chiapas are clear outliers because of their many avian species and a large surface area transformed to cropland (Fig. 3D); and cropland surface vs. endemic species, where Oaxaca, Jalisco, Sinaloa, and Michoacán are among the states with high avian endemism as well as large surfaces of cropland (Fig. 3E).

Oaxaca state analysis. Three factors accounting for $69.2 \%$ of the total variance in the data were selected (Table 5). Factor 1 contained the following correlated variables: total surface of the district (DIST_AREA), percentage of the district in relation to state's surface (\%_OF_ST), cropland surface (CROPLND), percentage of cropland in relation to district surface (\%_OF_Dist), total bird species (TOTAL_ $\mathrm{SP}$ ), and endangered species (ENDANGRD). This factor implies that the districts with the largest territorial surfaces and large croplands also have high avian biodiversity but many endangered species.

The high loading variables in the second factor, labeled "Population and poverty factor", were total population (TOT_POP), population density (POP_DENS), and poverty index (POV_IND). Finally factor 3, labeled "Natural vegetation factor", was represented by the natural vegetation surface (NAT_VEG) and its percentage from the total district surface (\%NATVEG). Two independent variables were found: cattle production units (CATTLE_ UTS) and endemic species (ENDEMIC) (Table 6).

Two regressions between the factors and the independent variables were statistically significant (Table 4). The regression between Factor 1 and Cattle production shows the largest districts with much cropland surfaces, high biodiversity, and threatened species like Juchitán, Tuxtepec, and Jamiltepec are also large producers of cattle (Fig. 4A). The other significant relationship was between the natural vegetation factor and the endemic species, where Miahuatlán, Ixtlán, and Yautepec districts showed more vegetation-covered areas and high values of avian endemism (Fig. 4B).

\section{Discussion}

Different studies have analyzed the relation between humans and the natural environments by 

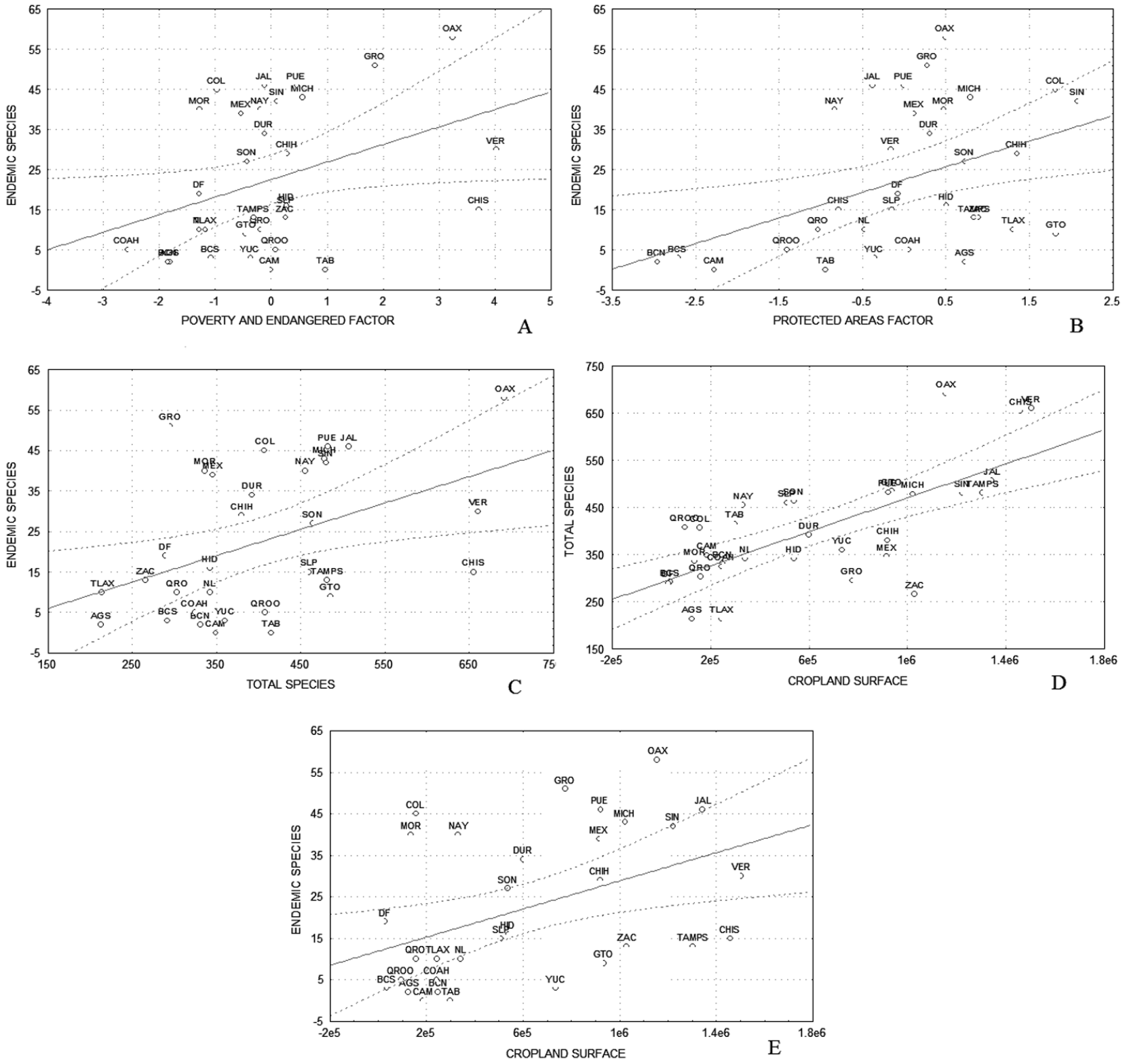

Figure 3. Linear regressions of the National analysis: A, poverty and endangered factor and Endemic species $\left(\mathrm{R}^{2}=0.13, p=0.05\right.$, $\mathrm{GL}=31) ; \mathrm{B}$, protected areas factor and Endemic species $\left(\mathrm{R}^{2}=0.14, p=0.02, \mathrm{GL}=31\right) ; \mathrm{C}$, total bird species and Endemic species $\left(\mathrm{R}^{2}=0.20\right.$, $p=0.01, \mathrm{GL}=31)$; $\mathrm{D}$, cropland surface and Total species $\left(\mathrm{R}^{2}=0.05, p=<0.0001, \mathrm{GL}=31\right)$; E, cropland surface and endemic species $\left(\mathrm{R}^{2}=0.19, p=0.01, \mathrm{GL}=31\right)$.

Table 5. Eigenvalues and percentage of the variance explained by the first 3 factors resulting from FA in the state analysis

\begin{tabular}{ccccc}
\hline & & \% total & Cumul. & Cumul. \\
\hline Factor & Eigenval & Variance & Eigenval & $\%$ \\
$\mathbf{1}$ & 6.736364 & 44.90909 & 6.73636 & 44.90909 \\
$\mathbf{2}$ & 2.017711 & 13.4141 & 8.75407 & 58.3605 \\
$\mathbf{3}$ & 1.63168 & 10.87787 & 10.38575 & 69.23837 \\
\hline
\end{tabular}

placing grids over a region and recording human and environmental variables in each cell of the grid (e.g. Balmford et al., 2001; Chown et al., 2003; Vázquez and Gaston 2006; Burguess et al., 2007). Most of these studies conclude that although national studies are necessary to start prioritizing conservation actions, finer-scale analyses are needed to identify areas where local conservation actions are necessary. 
Table 6. Loadings and communalities for each variable in the FA for the state analysis

\begin{tabular}{|c|c|c|c|c|c|c|c|c|}
\hline Loadings & $\begin{array}{c}\text { Factor } \\
1 \\
\end{array}$ & $\begin{array}{c}\text { Factor } \\
2 \\
\end{array}$ & $\begin{array}{c}\text { Factor } \\
3 \\
\end{array}$ & Communalities & $\begin{array}{l}\text { From } 1 \\
\text { Factor }\end{array}$ & $\begin{array}{l}\text { From } 2 \\
\text { Factors }\end{array}$ & $\begin{array}{l}\text { From } 3 \\
\text { Factors }\end{array}$ & $\begin{array}{l}\text { Multiple } \\
\text { R-Square }\end{array}$ \\
\hline DIST_AREA & 0.810810 & 0.012493 & 0.404649 & & 0.920874 & 0.922792 & 0.922879 & 0.928454 \\
\hline \%_OF ST & 0.747294 & 0.215470 & 0.381458 & & 0.920874 & 0.922792 & 0.922879 & 0.928454 \\
\hline CROPLND & 0.961121 & 0.034781 & 0.055634 & & 0.737587 & 0.739822 & 0.926127 & 0.924548 \\
\hline$\% \_O F$ DIST & 0.736325 & 0.201605 & -0.383989 & & 0.111349 & 0.111788 & 0.677105 & 0.740796 \\
\hline NAT_VEG & 0.381754 & 0.029296 & 0.786437 & & 0.260135 & 0.795336 & 0.825816 & 0.823340 \\
\hline$\%$ NATVEG & 0.310400 & 0.186233 & 0.677285 & & 0.045549 & 0.764764 & 0.765149 & 0.733571 \\
\hline TOT_POP & 0.675117 & -0.665576 & 0.042243 & & 0.248930 & 0.264763 & 0.267929 & 0.473048 \\
\hline POP_DENS & -0.104770 & -0.895252 & -0.184193 & & 0.003019 & 0.293426 & 0.434162 & 0.430764 \\
\hline CATTLE_UTS & 0.519590 & -0.157481 & 0.100569 & & 0.458309 & 0.467354 & 0.636403 & 0.722730 \\
\hline POV_IND & 0.087522 & 0.671119 & -0.149301 & & 0.542156 & 0.543058 & 0.697207 & 0.798348 \\
\hline TOTAL_SP & 0.849489 & -0.125614 & 0.379630 & & 0.765125 & 0.798737 & 0.826118 & 0.905137 \\
\hline ENDEMIC & 0.306012 & -0.080467 & 0.426414 & & 0.168948 & 0.173954 & 0.175523 & 0.522355 \\
\hline ENDANGRD & 0.841377 & -0.084608 & 0.336311 & & 0.766046 & 0.782821 & 0.817075 & 0.891113 \\
\hline Expl.Var & 6.092754 & 1.884303 & 2.408697 & & & & & \\
\hline Prp.Totl & 0.406184 & 0.125620 & 0.160580 & & & & & \\
\hline
\end{tabular}
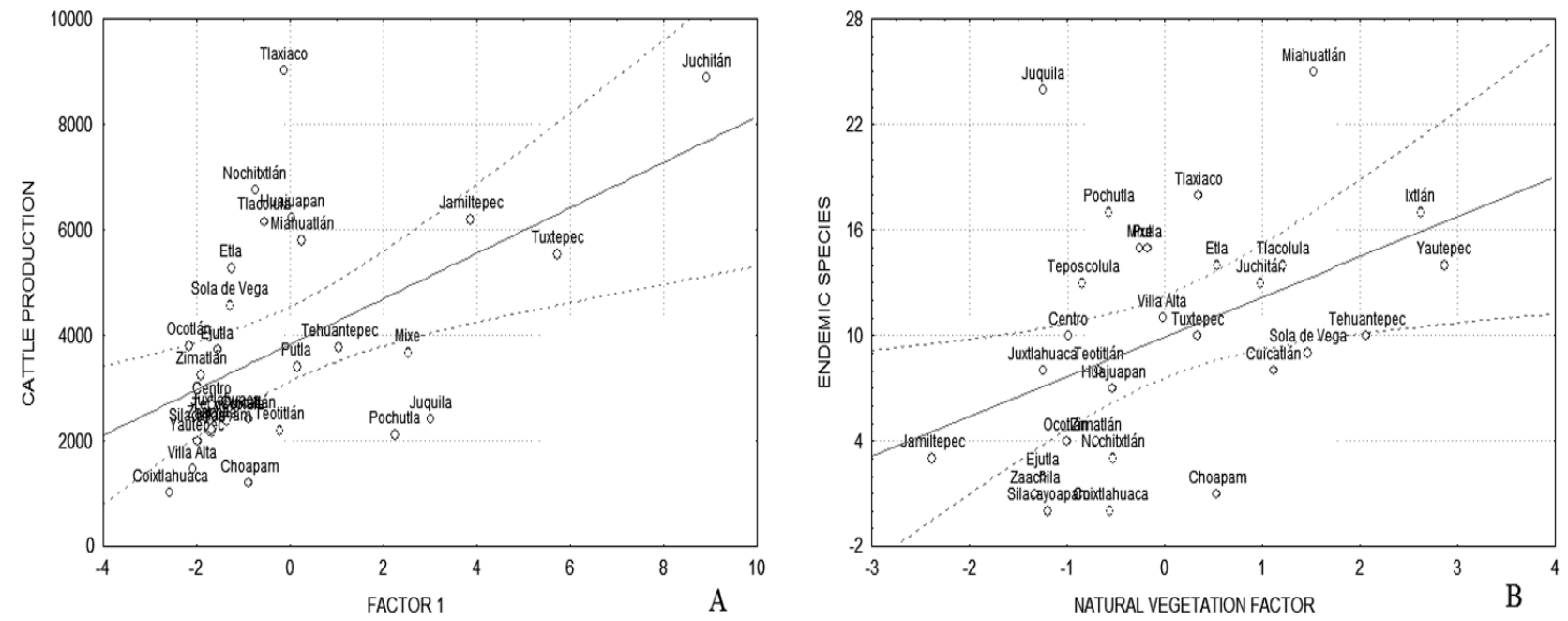

Figure 4. Linear regressions of the State analysis: $\mathrm{A}$, factor 1 and cattle production $\left(\mathrm{R}^{2}=0.27, p=0.003\right.$, $\left.\mathrm{GL}=29\right)$; $\mathrm{B}$, natural vegetation factor and endemic species $\left(\mathrm{R}^{2}=0.18, p=0.02, \mathrm{GL}=29\right)$.

In this study we used 2 different geopolitical scales to define our sample units at both national and state levels; such administrative boundaries are where most development and conservation policies take place. This kind of approach is critical to obtain a general overview of the environmental scenario, both nation- and statewide, and to set detailed conservation priorities with a more realistic human dimension that incorporates the ecosystem management and the political will and perception of environmental problems.

However, due to the social and environmental heterogeneity that prevails in Mexico, the relations between human activities, population, and natural variables yielded different results according to the geographical and geopolitical place where they were practiced. Likewise, different ecosystems react differently to the same threat depending on the location (Harcourt et al., 2001; SEMARNAT, 2002). As a consequence, conservation priorities are difficult to rate due to the contrasting social and cultural systems, the economic and political powers, and the biological conditions and environmental regulations of the country. Still, this study allowed us to group entities from 2 different geopolitical levels, according to both realistic information on their natural resources (bird richness and 
natural vegetation) and the intensity of human population and development. Once the states have been identified as a priority for conservation, an independent analysis of each one is needed in order to indicate regions where conflicts between conservation and human development are likely to be sever The states of Mexico. The national analysis showed that the total surfaces of all states were related to the natural vegetation present in them (Factor $1)$, with the largest states having more natural vegetation. However, the majority of these larger states are located in the north, a region mostly covered by xeric vegetation. In contrast, the central and southern states of Mexico have a more complex geography, diverse climates, ecosystems with a wider variety of vegetation types, and higher biodiversity (Challenger, 1998). It is estimated that $70 \%$ of the vegetation communities in Mexico are distributed over less than $5 \%$ of the total surface of the country (Velázquez et al., 2003).

The bird distribution in Mexico is influenced by different factors, including its geographic position between 2 bio-geographic zones, Nearctic and Neotropical, which provides Mexico with mixed characteristics from both (Navarro and Sánchez-González, 2003), and a complex topography that harbors several and distinct ecosystems, concentrating the highest avian richness in the centralsouthern tropical regions (Escalante et al., 1998). The significant relationship between total bird species and endemic species identifies states like Jalisco and Oaxaca as priorities for conservation, since the limited distribution of endemic species makes them more vulnerable to extinction (González-García and Gómez de Silva, 2002; Luck et al., 2003).

Bawa and Dayanandan (1997) related deforestation with socio-economic variables such as cattle grazing, grassland area, agriculture, and urban expansion, and found that habitat degradation processes were closely related to such activities in Latin America. Our study confirms this relationship, since some states with high values of human population are associated with high cattle production (Factor 2). This has serious implications for the conservation of ecosystems, as both urban expansion and cattle grazing are related to ecosystem loss.

Agricultural activities transform thousands of hectares of natural vegetation into cropland. These activities weaken the soil by removing nutrients, making it less suitable for agriculture, and where practiced without previous proper land evaluation, its continuous misuse results in degraded soils that are destined for cattle grazing or complete abandonment (Carabias, 1990). In some developing countries such as Mexico, human settlements expand towards areas that are more suitable for agriculture, with high soil fertility and more natural diversity, representing real and critical threats for the conservation of natural resources (Balmford et al., 2001; Luck et al., 2003). Our analysis agreed with this scenario, since cropland surface was highly related to both total and endemic species. Some of the states that practice intense agricultural activities, like Veracruz, Chiapas, and Oaxaca, also have considerable avian species as well as endemic species, and this must be taken into account for conservation activities and the planning of human activities.

Poverty is another human issue that has been related to environmental degradation and extinctions in developing countries (Kerr and Currie, 1995). We found a similar pattern in our study, since the poverty index and rural population were related to the number of endangered species in the same factor (Factor 3). Rural regions like Veracruz, Oaxaca, and Chiapas have higher rates of poverty and more endangered species. Some of these states also have high bird richness and endemism, implying high risks to the conservation of avian populations, since poverty is related to unsustainable exploitation of natural resources (Kerr and Currie, 1995).

Protected areas are surfaces with diverse natural ecosystems that have special relevance to conservation and are legally protected. Kerr and Currie (1995) considered that protected areas can help reduce biodiversity loss by maintaining habitats free from human disturbance. The linear regressions performed in the national analysis showed that some states with higher avian endemism like Oaxaca, Guerrero, and Michoacán do not have enough protected surfaces to protect their native biodiversity.

When we attempted to classify the states in terms of the opportunities and threats they have to the conservation of natural resources, a general national overview was quite clear; however, it was difficult to rank the states according to their conservation problems. For example, states like Michoacán and Durango showed the same conservation opportunities (high avian endemism and avian richness, large surfaces of natural vegetation, as well as many endangered species), but Michoacán presented more threats to conservation (high cattle production, large agriculture surfaces, and high poverty), than Durango. Therefore Michoacán can be considered a higher conservation priority than Durango, since the former has high biodiversity facing severe threats, while the latter has high biodiversity but did not present as many of the threats considered in this study (Fig. 5).

The districts of Oaxaca. At this geopolitical level, the factor analysis grouped many variables into the same factor (Factor 1): district surface, cropland, total birds, and endangered birds, probably because at a finer geographical scale, a more homogeneous distribution of territorial surface, natural resources, and human activities 


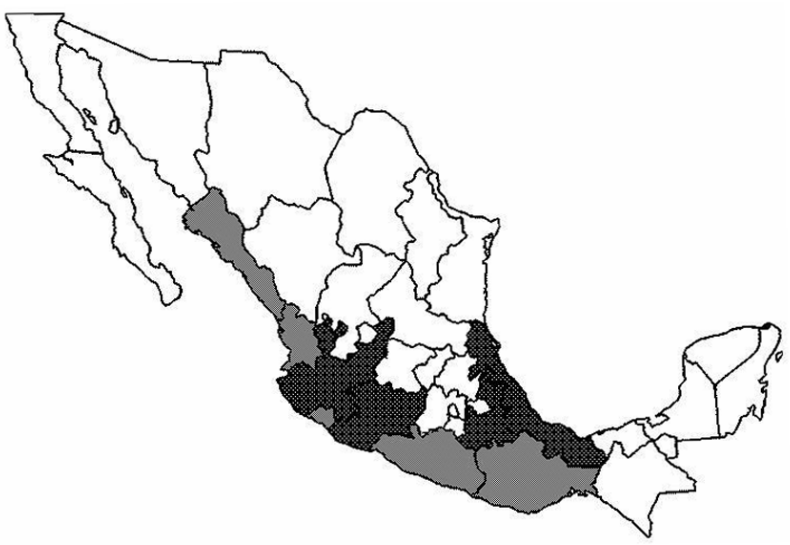

Figure 5. Overall states that need actions to the conservation of their natural resources. Darker states: Veracruz, Puebla, Michoacán, and Jalisco are the most endangered. Lighter states: Oaxaca, Guerrero, Colima, Nayarit, and Sinaloa are endangered to a lesser degree.

is apparent. Luck and collaborators (2003) relate the presence of human populations to biodiversity-rich areas, probably due to the soil fertility that harbors natural ecosystems and at the same time is suitable for agriculture practices, which has serious implications for conservation. This relation was found in the state analysis, because total bird species and cropland surface were included in the same factor. Also, as mentioned by Chown et al. (2003), the relationships among population distribution, human activities and species richness may change significantly with the reduction of the geopolitical scale being analyzed. Our study also agrees with this, since we detected that area is more related to human activities, total bird species, and endangered species at the district level than at the national level.

Oaxaca is one of the states with the highest bird richness and endemism in Mexico. This is a result of a complex local topography that creates diverse landscapes and ecosystems (Navarro et al., 2004). The inclusion of bird richness and endangered species with the practice of agricultural activities in the same factor highlights some districts that are a priority for conservation due to the habitat fragmentation imposed by agriculture practices.

Population and poverty variables were grouped in the same factor with opposing loads, suggesting that when population increases poverty diminishes. However, since rural population data are not available for the districts of Oaxaca, we only used total population. It is important to note that in Oaxaca a clear contrast exists between population distribution and poverty levels. While the majority of the population is rural, some districts like Centro, Juchitán, and Huajuapan concentrate most of the urban population with higher welfare standards and therefore present lower poverty levels. In contrast, the population in districts like Cuicatlán, Juquila, and Choapam is mostly rural and has very high levels of poverty. Such poverty is the result of a complex relation among geographical, political, social, and economic issues that make Oaxaca one of the poorest states in the country. It is estimated that less than $2 \%$ of the population in the state has access to education, housing or regular economic income or lives in cities with complete services (www.oaxaca.gob.mx). The population in these high-poverty districts has to work on farms with inadequate sanitary and working conditions, a situation that exerts a strong pressure on the environment and enhances poverty levels, since they generally lack proper poverty alleviation programs (Leff, 1990; FNUAP, 1991).

Due to the biogeographical location and the physical features of Oaxaca, it is one of the most biodiverse regions of the world, and includes all the vegetation types present in Mexico (Velázquez et al., 2003). An interesting issue that was revealed from the state analysis was that the natural vegetation is not distributed in the larger geopolitical units as in the national analysis. The districts with more natural vegetation like Miahuatlán, Tehuantepec, and Yautepec are located in the southeastern mountain ranges, identified as a physiographic region by CONABIO (www.conabio. gob.mx). In this study we found that natural vegetation is significantly related to the presence of endemic species, and the relevant districts in both terms represent a clear priority for conservation actions, since recent estimates suggest that by the year 2022, only a minor part of the state $(22 \%)$ will remain covered by the native natural vegetation (Velázquez et al., 2003).

Another major threat to conservation is cattle grazing, one of the most profitable activities in Oaxaca. Most of the cattle production in the state is done by small producers that free their animals to graze on the natural vegetation (Villegas-Durán et al., 2001). We found a significant relation between Factor 1 and cattle production, and because this factor includes agricultural activities (cropland surface), the relationship with cattle production indicates a high human pressure on natural resources, since both activities are fragmenting habitat and removing natural vegetation (Table 4). The application of inadequate policies has encouraged conversion of natural vegetation to croplands and cattle grazing areas, therefore, these areas are in need of proper management in order to plan such economic activities, but also to perform activities of environmental conservation and/or restoration.

At this smaller scale we grouped the districts according to the opportunities and threats to conservation as we did in the national analysis. The districts of Miahuatlán and Ixtlán presented more opportunities for conservation (large natural vegetation surfaces, high avian richness, and 
many endemic and endangered species); however, while Miahuatlán showed more threats to biodiversity (large cropland surface, high cattle production, large population, and high poverty), Ixtlán did not present major threats to conservation in relation to the variables included in this study. According to our results, we tried to arrange the rest of the districts according to their different opportunities and threats to conservation. Thus districts like Juchitán and Tehuantepec presented the same opportunities for conservation (large natural vegetation surface, high avian richness, and many endangered species); however the former presented many more threats to conservation (large cropland surface, high cattle production, and large population) than the latter, which only had a large population. Therefore Juchitán can be considered a priority district where conservation actions are urgently needed (Fig. 6).

The integrated analysis of environmental and socioeconomic variables to explore conservation priorities, both nation- and statewide, is useful to identify areas with high biodiversity (in our case avian richness and natural vegetation) that might face conservation threats due to intense anthropogenic activity. Using geopolitical units is a relevant issue since these are the levels in which laws and rules are applied, executed, and enforced. Such laws regulate the environmental, economic, and demographic activities and must work in a consistent manner, so as to offer major benefits to all sectors involved. These kind of exploratory studies are necessary to identify the areas that need planning of the economic activities, as well as proper actions to preserve the natural environments.

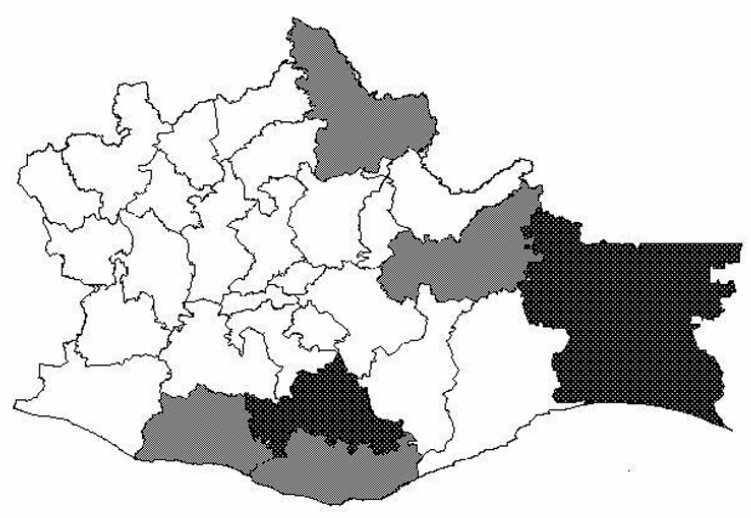

Figure 6. Oaxaca overall priority districts that need actions to the conservation of their natural resources. Darker districts: Miahuatlán and Juchitán are the most endangered. Lighter districts: Pochutla, Juquila, Mixe, and Tuxtepec are endangered in a lesser degree.
An important issue that is worth mentioning is the lack of precise and localized environmental information on biodiversity at both national and state levels in Mexico. It is imperative to broaden scientific fieldwork that generates local biological information to strengthen the natural knowledge and provide data to support environmental policies.

Finally, future investigations should consider widening these types of exploratory approaches by including different taxa and other socioeconomic variables, in order to further understand the patterns of interaction between humans and the natural environments. This scientific approach may assist both state and national decision-makers to define effective priorities for long term conservation of natural resources.

\section{Acknowledgments}

We are grateful for the data provided by the personnel at Instituto Nacional de Ecología (INE), Instituto Nacional de Estadística, Geografía e Informática (INEGI), Comisión de Áreas Naturales Protegidas (CONANP), and Secretaria de Medio Ambiente y Recursos Naturales (SEMARNAT). E Wehncke was very helpful with the data and analysis of results and LB Vazquez, RA Medellín, and N Jacobson made important comments that helped improve this manuscript.

\section{Literature cited}

Araújo, M. B. 2003. The coincidence of people and biodiversity in Europe. Global Ecology \& Biogeography 12:5-12.

Balmford, A., J. L. Moore, T. M. Brooks, N. Burgess, L. A. Hansen, J. C. Lovett, S. Tokumine, P. Williams and I. Woodward. 2001. People and biodiversity in Africa. Science 293:1591-1592.

Bawa, K. S. and S. Dayanandan. 1997. Socioeconomic factors and tropical deforestation. Nature 386:562-563.

Brooks, T. M., S. L. Pimm and J. O. Oyugi. 1999. Time lag between deforestation and bird extinction in tropical forest fragments. Conservation Biology 13:1140-1150.

Burgess, N. D., A. Balmford, N. J. Cordeiro, J. Fjeldsa, W. Küper, C. Rahbek, E. W. Sanderson, J. P. W. Scharlemann, J. Henning-Sommer and P. H. Williams. 2007. Correlations among species distributions, human density and human infrastructure across the high biodiversity tropical mountains of Africa. Biological Conservation 134:164-177.

Carabias, J. 1990. Las políticas de producción agrícola, la cuestión alimentaria y el medio ambiente. In Medio Ambiente y Desarrollo en México, E. Leff (ed.). Centro en Investigaciones Interdisciplinarias en Humanidades, UNAM. $766 \mathrm{p}$. 
Ceballos, G. 1993. La extinción de especies. Ciencias. Núm. Especial 7:5-10.

Ceballos, G. and L. Márquez. 2000. Las aves de México en peligro de extinción. CONABIO-UNAM-FCE. México. $430 \mathrm{p}$.

Cincotta, R. P., J. Wisnewski and R. Engelman. 2000. Human population in the biodiversity hotspots. Nature 404:990-992.

CONAPO (Consejo Nacional de Población). 2001. México en cifras. México.

Challenger, A. 1998. Utilización y conservación de los ecosistemas terrestres de México. Pasado, presente y futuro. CONABIO-IB-Sierra Madre. 847 p.

Chown, S. L., B. J. van Rensburg, K. J. Gaston, A. S. L. Rodríguez and A. S. Van Jaarsveld. 2003. Energy, species richness, and human population size: conservation implications at a national scale. Ecological Applications 13:1233-1241.

DOF. 2002. NOM-059-ECOL-2001. Norma Oficial Mexicana sobre la protección ambiental-especies nativas de México de flora y fauna silvestres-categoría de riesgo y especificación es para su inclusión, exclusión o cambio-lista de especies en riesgo. Diario Oficial de la Federación, 6 de marzo de 2002.

Ehrlich, P. R. 1995. The scale of the human enterprise and biodiversity loss. In Extinction rates, J. H. Lawton and R. M. May (eds.). Oxford University Press. Oxford. p. 214-226.

Ehrlich, P. R. and G. Ceballos. 1997. Población y medio ambiente: ¿Qué nos espera? Ciencia 48:19-30

Escalante, P., A. G. Navarro and A. Townsend Peterson. 1998. Un análisis geográfico, ecológico e histórico de la diversidad de aves terrestres de México. In Diversidad Biológica de México, T. P. Ramamoorthy, R. Bye, A. Lot and J. Fa. (eds.). Instituto de Biólogía, Universidad Nacional Autónoma de México. 792 p.

Fondo de Población de las Naciones Unidas (FNUAP). 1991. La población, los recursos y el medio ambiente. Los desafíos críticos. Fondo de Población de las Naciones Unidas. London, UK.

González-García, F. and H. Gómez de Silva-Garza. 2002. Especies endémicas: riqueza, patrones de distribución y retos para su conservación. In Conservación de aves. Experiencias en México, H. Gómez de Silva and A. Oliveras (eds.). CIPAMEX. p. 150-194.

Harcourt, A. H., S. A. Parks and R. Woodroffe. 2001. Human density as an influence on species/area relationships: double jeopardy for small African reserves? Biodiversity and Conservation 10:1011-1026.

INEGI (Instituto Nacional de Estadística, Geografía e Informática). 2003. Anuario de Estadísticas por Entidad Federativa 1995-2002. México, D.F. 688 p.

Iñigo-Elias, E. and M. Ramos. 1991. The psittacine trade in México. In Neotropical wildlife use and conservation, J. Robinson and K. Redford (eds.). The University of Chicago Press. p. 380-392.
Johnson, D. E. 1998. Métodos multivariados aplicados al análisis de datos. Thomson Eds. 566 p.

Kerr, J. T. and D. J. Currie. 1995. Effects of human activity on global extinction risk. Conservation Biology 9:1528-1538.

Leff, E. 1990. Medio Ambiente en México. Prefacio. In Medio Ambiente y Desarrollo en México, E. Leff (ed.). Centro en Investigaciones Interdisciplinarias en Humanidades, UNAM. $766 \mathrm{p}$.

López-Medellín, X. 2003. Evaluación del comercio de aves canoras y de ornato en México 1970-2001. Tesis, Facultad de Ciencias, Universidad Nacional Autónoma de México. México, D. F. 83 p.

Luck, G. W., T. H. Ricketts, G. C. Daily and M. Imhoff. 2004. Alleviating spatial conflict between people and biodiversity. Proceedings of the Natural Academy of Sciences 101:182-186.

Lutz, W., W. Sanderson and S. Scherbov. 2001. The end of world population growth. Nature 412:543-545.

Mas, J. F., A. Velázquez, J. R. Díaz-Gallegos, R. MayorgaSaucedo, C. Alcántara, G. Bocco, R. Castro, T. Fernández and A. Pérez-Vega. 2004. Assessing land use/cover changes: a nationwide multidata spatial database for México. International Journal of Applied Earth Observation and Geoinformation 5:249-261.

Maurer, B. A. 1996. Relating human population growth to the loss of biodiversity. Biodiversity Letters 3:1-5.

McKinney, M. L. 2002. Why larger nations have disproportionate threat rates: area increases endemism and human population size. Biodiversity and Conservation 11:1317-1325.

Navarro, A. G. and L. A. Sánchez-González. 2003. La diversidad de las aves. In Conservación de aves. Experiencias en México, H. Gómez de Silva and A. Oliveras (eds.). CIPAMEX. p. 24-85.

Navarro, A. G., E. A. García-Trejo, A. T. Peterson and V. Rodríguez-Contreras. 2004. Aves. In Biodiversidad de Oaxaca, A. J. García-Mendoza and M. Briones-Salas (eds.). Instituto de Biología-UNAM - Fondo Oaxaqueño para la Conservación de la naturaleza - World Wildlife Fund, México. p. 391-421.

Peterson, T., S. L. Egbert, V. Sánchez-Cordero and K. P. Price. 2000. Geographic analysis of conservation priority: endemic birds and mammals in Veracruz, Mexico. Biological Conservation 93:85-94.

Ricketts, T. N., E. Dinerstein, T. Boucher, T. M. Brooks, S. H. M. Butchart, M. Hoffmann, J. F. Lamoreux, J. Morrisno, M. Parr, J. D. Pilgrim, A. S. L. Rodrigues, W. Sechrest, G. E. Wallace, K. Berlin, J. Bielby, N. D. Burgess, D. R. Church, N. Cox, D. Knox, C. Loucks, G. W. Luck, L. W. Master, R. Moore, R. Naidoo, R. Ridgely, G. E. Schatz, G. Shire, H. Strand, W. Wettengel and E. Wikramanayake. 2005. Pinpointing and preventing imminent extinctions. Proceedings of the National Academy of Sciences 
51:18497-18501.

Seabloom, E. W., A. P. Dobson and D. M. Stoms. 2002. Extinction rates under non random patterns of habitat loss. Proceedings of the Natural Academy of Sciences 99:11229-11234.

SEMARNAT (Secretaría de Medio Ambiente y Recursos Naturales). 2002. Informe de la situación del Medio Ambiente en México 2002.

Soulé, M. E. 1991. Conservation: tactics for a constant crisis. Science 253:744-750.

Soulé, M. E. and M. A. Sanjayan. 1998. Conservation targets: Do they help? Science 279:2060-2061.

Thompson, K. and A. Jones. 1999. Human population density and prediction of local plant extinction in Britain. Conservation Biology 13:185-189.

Tilman, D., J. Fargione, B. Wolff, C. D’Antonio, A. Dobson, R. Howarth, D. Schindler, W. H. Schlesinger, D. Simberloff and D. Swackhamer. 2001. Forecasting agriculturally driven global environmental change. Science 292:281-284.

Vázquez, L. B. and K. J. Gaston. 2006. People and mammals in México: Conservation conflicts at a national scale. Biodiversity \& Conservation. 15:2397-2414.

Velázquez, A., E. Durán, I. Ramírez, J. F. Mas, G. Bocco, G. Ramírez and J. L. Palacio. 2003. Land use-cover changes processes in highly biodiverse areas: the case of Oaxaca, Mexico. Global Environmetnal Change 13:175-184.

Villegas-Durán, G., A. Bolaños Medina and L. Olguín Prado. 2001. La ganadería en México. Textos Monográficos: 5. Economía. Instituto de Geografía-UNAM. Plaza y Valdés. 158 p.

Waide, R. B., M. R. Willig, C. F. Steiner, G. Mittelbach, L. Gough, S. I. Dodson, G. P. Juday and R. Parmenter. 1999. The relationship between productivity and species richness. Annual Review of Ecology and Systematics 30:257-300. 